\title{
Correction to: CAEP/ACMU 2021 Scientific Abstracts
}

June 15 - 17th, 2021

Published online: 5 January 2022

(c) Canadian Association of Emergency Physicians (CAEP)/ Association Canadienne de Médecine d'Urgence (ACMU) 2021

\section{Correction to: \\ Canadian Journal of Emergency Medicine (2021) 23 \\ (Suppl 1):S1-S93 \\ https://doi.org/10.1007/s43678-021-00138-3}

In abstract MP4, "Impact of major health information technology failures on the emergency department", the order that the authors appeared in the author list was incorrect. The correct order is: V. Homier, MD, MSc, H. Gangatharan, BMSc, M. Bouchard, M. Beique, BSc, MD. The original article has been corrected.

The original article can be found online at https://doi.org/10.1007/ s43678-021-00138-3. 